exposed well to view. In some genera it is important to open the mandibles and expose the male genitalia. Any such treatment is always better accomplished in relaxed specimens than in fresh ones, the parts in the latter tending to return to their former positions. Every specimen should be labelled with the date and locality of capture, and the collector's name written or printed in very small, clear letters on a small, white card. Collect preferably only newly emerged, unfaded specimens, not dusted with pollen, and do not be afraid to make a large collection. How pleasantly the collector can spend an hour now and then during our long winter, arranging the summer's material into species, according to similarities in sculpture and livery, guided by nature, musing the while on the possible value to the species of some remarkable structures or pattern of colours! A study of the insects in the field, or of their marvellously diverse and interesting nesting habits, will confute or endorse many a theory thus formed.

SOME DRAGONFLIES FROM PRINCE EDWARD ISLAND.

BY E. M. WALKER, TORONTO.

Somewhat more than a year ago I received from Dr. A. G. Huntsman, Curator of the Dominion Biological Station, St. Andrews, N.B., a number of dragonflies, including a few nymphs, which he very kindly collected for me during a few days spent in Prince Edward Island in the summer of 1915.

Hitherto there have been apparently no records of dragonflies from this Province, so that, although the number of species listed here is small, and doubtless represents but a fraction of the Odonate fauna of this island, it seems worth while to record them.

All of the species are widely distributed, and with one exception all could have been predicted almost with certainty to occur in this region.

The localities and dates of collection are as follows:-

Charlottetown, pond in Victoria Park, Aug. 3.

Souris, pond on New Harmony Road, Aug. 1.

Little Harbour, near Souris, Aug. 14.

Souris, Sept. 5.

Rollo Bay, Aug. 21.

April, 1917 
1. Lestes congener Hag. Eleven nymphs, 8 full grown and 3 belonging to the penultimate stage, were taken from the pond on New Harmony Road, Souris.

2. Lestes unguiculatus Hagen. Charlottetown, 2 o or, $^{2}$ 우 ; New Harmony Road, Souris, several nymphs from the pond, probably belonging to this species.

3. Lestes uncatus Kirby. Charlottetown, $10^{7}$.

4. Lestes disjunctus Selys: Charlottetown, 1. ఠ, 1 ㅇ Little Harbour, Souris, $2 \sigma^{7} \mathrm{~s}, 4$ 우 $\mathrm{s}$; Rollo Bay, 1 우.

These four species of Lestes seem to be generally distributed in the Canadian and Transition zones from Atlantic to Pacific. It will be noticed that the same four species and no others are included in Mr. Whitehouse's list from Red Deer, Alta., (Can. Ent., vol. XLIX, 1917, p. 96).

5. Nehalennia irene Hagen. New Harmony Road, Souris, $1.0^{7}$.

6. Ischnura verticalis Say. New Harmony Road, 1 ; Little Harbour, Souris, 6 o $^{7} \mathrm{~s}, 7$ i s; Rollo Bay, 2 o $^{7} \mathrm{~s}, 6$ o s.

One of the males from Souris is somewhat teneral, the others are fully mature, the females all pruinose.

7. Enallagma hageni Selys. Charlottetown, 2 o's; New Harmony Road, 3 क s; Little Harbour, 8 o's.

This and the preceding two species are unknown in the western half of the continent; Nos. 5 and 7 ranging into Manitoba, while No. 6 has not been taken in Canada, west of Nipigon, Ont.

8. Enallagma civile Hagen. Souris, Sept. 5, 1 ot in full colour.

This is chiefly a western species, and is rare in Canada. Its occurrence in Prince Edward Island was unexpected, although there is an old record of its capture in Quebec. I have also received it from Manitoba.

9. Eshna interrupta interrupta E. Walker. Little Harbour, $1 \sigma^{x}$. The spots formed by the interrupted lateral thoracic bands are rather large and rounded, though completely separated. New Harmony Road, one full-grown female nymph.

10. Eshna umbrosa E. Walker. Charlottetown, fragments of two male exuvia from pond, apparently this species; New Harmony Road, one $\sigma^{\pi}$ exuvia and four very young nymphs. 
11. Somatochlora elongata Scudd. Rollo Bay, 1 or. Not known west of Wisconsin.

12. Libellula quadrimaculata L. Charlottetown, $3 \sigma^{7} s$; New Harmony Road, 4 nymphs, two belonging to the penultimate stage, the others younger.

13. Sympetrum obtrusum Hagen. Charlottetown, $5 \sigma^{x} s, 2$ $q \mathrm{~s}$, two of the $\sigma^{x} \mathrm{~s}$ recently emerged; Little Harbour, $2 \sigma^{7} \mathrm{~s}$; New Harmony Road, 1 full-grown nymph.

14. Sympetrum rubicundulum Selys. Charlottetown, $3 \sigma^{\pi} \mathrm{s}$; Little Harbour, $1 \sigma^{\gamma}$, New Harmony Road, $1 \sigma^{7} 3$ s., all teneral.

15. Leucorrhinia hudsonica Selys. New Harmony Road, 2 nymphs, penultimate and ante-penultimate stages.

This and the preceding three species are transcontinental species, $L$. hudsonica being confined to the boreal region.

- 16. Leucorrhinia intacta Hagen. New Harmony Road, one nymph of the penultimate stage apparently belonging to this species. Another similar younger nymph was also found.

Distributed as far west as Alberta, (see Mr. Whitehouse's list, Can. Ent., vol. XLIX, p. 96.) but not common in the Canadian Zone.

\section{THE STATUSS OF LECANIUM CORNI BOUCHE IN NEW JERSEY (HOMOP.)}

BY HARRY B. WEISS, NEW BRUNSWICK, N.J.

This insect is undoubtedly the best recorded of all the species listed in Smith's "Insects of New Jersey," inasmuch as it appears at least eleven times disguised under as many synonyms. J. G. Sanders, in his paper, "The Identity and Synonymy of Some of Our Soft Scale Insects," (Jour. Econ. Ent., 1909, p. 428) mentions 41 or 42 synonyms of Lecanium corni Bouche, and eleven of them managed to appear in Smith's list.

Sanders states that it is widely distributed in North America, the most important hosts being plum, peach, apricot, pear, currant, blackberry, mulberry, csage orange, elm, ash, linden, pecan, maple, Cornus, etc. It also occurs in Europe in greenhouses on peách and grape and outside on various plants including currants, gooseApril, 1917 